\title{
Die funksie van ruimte in die reisverhale in 1
}

\section{Henog 12-36}

\author{
P M Venter \\ Departement Ou-Testamentiese Wetenskap \\ Universiteit van Pretoria
}

\begin{abstract}
The function of space in the travel narratives of 1 Enoch 12-36

Using the theories of Malbon and Van Eck on the functional use of space in narratives, a narrative analysis is presented of Enoch's account of three journeys in 1 Enoch 12-36. In the microsocial world of these narratives focal space is used as expression of the symbolic universe of the apocalyptic author(s). According to this view cosmological space is allocated by God as either a place of punishment for the disobedient or as a refuge for the faithful. In this knowledge the author(s) of the apocalypse found security when they experienced crises during the third and second century BCE. Preference for spatial rather than chronological data in apocalyptic thinking at this early stage of apocalypticism is described against the background of the influence of wisdom literature and the concept of holiness.
\end{abstract}

\section{INLEIDING}

Apokaliptiese literatuur is in die eerste instansie verhaalliteratuur. Adela Yarbro Collins (1996:7) wys dit ook uit in haar definisie van die apokalips as “....a genre of revelatory literature with a narrative framework, in which a revelation is mediated by an otherwordly being to a human recipient, disclosing a transcendent reality which is both temporal, insofar as it envisages eschatological salvation, and spatial, insofar as it involves another, supernatural world...". Ek kursiveer in hierdie aanhaling narrative framework om aan te dui dat die apokalips as verhaal gelees moet word. Martha Himmelfarb (1993:102) het aangedui dat die neiging “... to strip away the 'narrative' frame to get to the revelatory core" iets van die betekenis van die apokalips verlore laat gaan. Die apokalips is na alles 'n beplande intertekstuele oefening waarin die uitbeelding van die ervarings van die held verstaan moet word as "... an act of imagination, with its 
specifics determined by the author's manipulation of conventions, rather than as a literary representation of the author's own experience" (Himmelfarb 1993:98).

Die transendentale werklikheid wat in die vertelling geopenbaar word, het sowel 'n temporele as 'n ruimtelike aspek. Die neiging bestaan by baie lesers om die temporele aspek te beklemtoon ten koste van die ruimtelike aspek. Malina beweer selfs dat die hede-georiënteerde vertikaalgerigde astrale profesie in 'n apokalips soos Openbaringe, deur baie lesers omgebuig word na 'n toekomsgerigde horisontaal-georiënteerde voorspelling. Malina (1995:266) sê: “.... [T]he prophet's cosmic journeying to explain the present becomes an ideology of future-oriented, social transformation". Dit dui op die verwaarlosing van die ruimtelike aspek in die lees van apokalipse. Hierdie skeeftrekking is strydig met die belang wat daar in apokaliptiese verhale aan ruimte geheg word.

Een van die verhaalgenres waarvan in apokalipse gebruik gemaak word, is dié van die reisverhaal. In die reisverhaal gaan dit juis oor ruimte. As 'n vorm van beskrywingskuns is dit een van die oudste tipes vertellings in die wêreld. Homeros se Odusseia uit ongeveer 850 v C, Herodotus se Historiae uit die vyfde eeu v C en Xenophon se Anabasis uit dieselfde tyd, is voorbeelde van hierdie vorm van vertelling. Die uitstaande eienskap van die reisverhaal is dat alle reisindrukke vertel en beskryf word uit die gesigshoek van die reisiger-waarnemer en die teoretiese dualiteit tussen skrywer en fiktiewe verteller daardeur opgehef word. Dit maak hierdie genre besonder bruikbaar vir die apokalips. Die “... kenmerk van die strukturele organisasie van die reisprosa ... dat die persoonlikheid van die waamemer-verteller ten nouste met dié ruimtebeskrywing geïntegreer is" (Cloete 1992:421) en dat die reiservaring “... een belangrijke rol speelt, zonder dat ze echter het hoofdmotief van het werk moet zijn" (Van Gorp 1991:341), leen sigself in besonder tot ' $n$ geopenbaarde interpretasie van die kosmiese wêreldtoneel.

"Die gerigtheid van die reisiger-waarnemer op 'n empiriese ruimte en meer bepaald op 'n onmiddellike fisiese ruimte, bring mee dat dikwels meer klem op die spesifieke konstituerende elemente gelê word" (Cloete 1992:421). Terwyl die elemente van karakterisering en veral uitbeelding van tyd in apokalipse prominent staan, geniet ruimtebeelding in die apokalipse waarin die reisgenre gebruik word, die voorkeur. Binne die dualisties-mitologiese denkraamwerk van die apokaliptikus en sy visionêre belewenis, sluit die reiservaring die aardse sowel as die hemelse ruimtes in. Terwyl die klem dus baie sterk op ruimtebeelding lê, moet die groter opset van die verhaal egter nie verwaar- 
loos word nie. Die taal en soms fantasmagoriese beelde waarmee hierdie ruimtes beskryf word, maak Himmelfarb se waarskuwing om nie die apokalips van die vertelraamwerk daarvan los te maak nie, baie belangrik. Van Gorp se aanduiding hierbo dat die reiservaring nie noodwendig die hoofmotief van die beskrywing is nie, is veral by die apokalips van belang. Die ruimtebeelding bly steeds deel van 'n groter vertelling wat die waarnemer-verteller gebruik om die openbaring wat eksklusief ontvang is, aan ander oor te dra.

\section{PROBLEEMSTELLING}

Reisverhale kom voor in verskillende Bybelse, apokriewe en pseudepigrafiese apokalipse. Reise na die hemel kom baie meer voor as aardse reise. Himmelfarb (1993) hanteer in haar ondersoek na hemelse reise (ascent apocalypses) onder andere die pseudepigafiese Boek van die Wagte in die Etiopiese Henog (1 Henog 1-36). Sy sien in aansluiting by Nickelsburg die verhaal oor die engele wat by aardse vrouens reuse as kinders verwek (1 Henog 6-11) as 'n ouer verhaal waarby die outeur(s) van die Boek van die Wagte nog verdere materiaal bygewerk het. Hy/hulle het die vertelling van die bemiddeling van Henog vir die engele, en sowel sy hemelreis (1 Henog 12-16) as sy aardse reis in die geselskap van die engele (1 Henog 17-19), intertekstueel geskep en by die ouer vertelling aangelas. 'n Ander outeur het die profesie oor die eindtyd (1 Henog 1-5) as 'n inleiding vir die hele boek geskryf. Hy het ook die tweede aardse reis van Henog (1 Henog 20-36) as 'n uitbreiding op die eerste reis by 17-19 bygevoeg “... intended to spell out some of the themes of the first yourney and to establish its relationship to the sacred geography of the Bible" (Himmelfarb 1993:103).

Himmelfarb konsentreer in haar studie op die literêre genre van hemelse reise. Sy dui aan dat hierdie genre ontstaan het tussen die twee pole van literêre nalatenskap en eietydse Grieks-Romeinse denke. Apokalipse wat in hierdie genre geskryf is steun op “... an understanding of heaven as a temple with angels and heavenly priests, and ... the emergence of the idea of heavenly ascent in the apocalypses is closely related to the development of this picture of heaven" (Himmelfarb 1993:4). In aansluiting by die literêre nalatenskap van die visioene van Esegiël 1:8-11:43, die tempelvisioen in Jesaja 6 en Miga ben Himla se hemelvisie (1 Konings 22:19-22), word die hemel gedurende die 
tweede eeu v C al meer as die oorspronklike model gesien waarvan die aardse tempel 'n afbeelding is. ' $n$ Hemelreis en besoek aan God waar God in die hemel op die troon sit, is 'n besoek aan die hemelhof waar die beslissings gemaak word oor die kosmos.

Himmelfarb het daarop gewys het dat die apokalips nie van die verhalende raamwerk daarvan losgemaak kan word nie. Sy hou haar egter veelmeer besig met Gattungsforschung as narratiewe analise. Sy bestudeer die genre van die hemelvaart-apokalips in die Boek van die Wagte meer vanuit die intertekstuele en sosio-historiese konteks daarvan as vanuit die struktuur van die verhaal self. Die verhaal van die reis na die hemel in 12-16 verwys immers terug na 6-11. Die vertellings van die twee aardse reise in 17-19 en 20-36 maak eweneens nie sin uit sonder die vertelling in 12-16 nie. Die gedeeltes moet almal saam as episodes van ' $n$ langer vertelling gelees word. Himmelfarb het die reis na die hemel (12-16) nie binne die makrokonteks van hierdie groter verhaal gelees nie. Die diakroniese teorie wat sy aanhang oor die ontstaan van die verhaal het haar weerhou om ook sinkronies na die eindvorm van die verhaal te gaan kyk. Die twee reise oor die aarde $(17-19 ; 20-36)$ moet in samehang met die reis na die hemel (12-16) gelees word. Hemelreis en aardse reis wig hier by mekaar in. Dit is dus ' $n$ leemte in haar werk, maar ook in die Henognavorsing oor die algemeen. Hierdie aspek het nog nie die nodige aandag ontvang nie. Selfs in die voordrag van J C Thom oor aspekte van die vorm, betekenis en funksie van die Boek van die Wagte voor die NTWSA in 1983, is hy daarvoor gekritiseer dat hy wel die werk as narratief beskou "... but has not dealt nearly consistently enough with the Book of the watchers as a narrative" (Combrink 1983:49). Dit is 'n leemte in die navorsing wat opgevul moet word.

My narratologiese analise van hoofstukke 12 tot 36 wil egter nog verder gaan en ook nog ondersoek instel na die rol wat ruimte in apokaliptiese denke speel. Hahn (1998:52-3) praat van die kosmiese werklikheid in die Boek van die Wagte as "....eine apokalyptisch adaptierte Kosmologie". Tyd, maar ook ruimte, speel 'n rol in apokalipse. Collins (1996:7) het hierbo die apokalips beskryf as die openbaring van 'n transendentale werklikheid op twee maniere: “... temporal, insofar as it envisages eschatological salvation, and spatial, insofar as it involves another, supernatural world ... (my kursivering). Die gevalle waarin die uitbeelding ruimtelik geskied, is egter statisties by verre in die minderheid. Die verdere en eintlike probleem is dat wanneer dit wel ruimtelik 
geskied, dit nie altyd in terme van 'n bo-natuurlike ruimte is nie. Die Boek van die Wagte is hiervan ' $n$ voorbeeld'.

Wanneer hierdie gedeeltes verhaalmatig ondersoek word as reisverhale, val die fokus vanselfsprekend op die gebruik van vertelruimte in die verhale. Die narratiewe funksionaliteit van ruimte dra direk by tot die bedoeling van die verhaal (en dus tot die bedoeling van die apokalips). Himmelfarb het in haar Gattungsforschung wel aandag gegee aan die vertelde ruimte of alledaagse ruimte wat in die verhale reflekteer word, maar nie aan die manier waarop dit as vertelruimte in die vertelling aangebied word nie. Om in die verhaalontleding van die apokalipse aandag te gee aan die funksie van ruimte in die vertelling, wat die gewone aardse ruimtes insluit, sal ook iets ontsluit van die rol wat kosmiese ruimtes speel in die ideologiese perspektief van die eerstepersoonsverteller. Iets van wat Himmelfarb genoem het die "sacred geography of the Bible" (1993:103), en van die ideologiese beskouing van die rol van ruimtes in die makrososiale wêreld van die apokaliptiese simboliese universum van die werklike verteller uit die derde / tweede eeu $\mathrm{v}$ C ( vgl Stone 1978:483-486), sal deur so 'n ondersoek duidelik word. Ook die manier waarop daar naas hemelse ruimtes van aardse ruimtes gebruik gemaak word in die oordra van die ideologiese perspektief van die apokaliptiek, sal duideliker na vore kom. Dit behoort op sy beurt ons te help om meer te verstaan van die inhoudgewing, historiese gang en ontwikkeling van die apokaliptiese bewussyn..

\section{3. 'N TEORETIESE VERTREKPUNT}

Malbon (1986:3) het in die lig van Lévi-Strauss se siening van die mite as 'n "... progressive mediation of a fundamental opposition", die gebruik van ruimte in die verhaal van Markus ondersoek. In die kleinste essensiële en volledige eenhede eien sy reeds bondels van ruimtelike relasies wat opponerend teenoor mekaar staan, maar in die geheel van die verhaal 'n sinvolle patroon vorm. Sy werk met drie soorte ruimtes: geopolitiese ruimtes (benoemde streke, stede en dorpe), topografiese ruimtes (fisiese verskynsels van die aarde soos die see, wildernis en oseaan) en argitekturele ruimtes (mensgemaakte

\footnotetext{
1 Hahn beskryf die reisverhale in 21-36 ook as "Himmelsreise" (1998:53). Die uitdruklike verwysing na, byvoorbeeld, plekke soos Dan in 13:7-8, wys dat dit ook 'n reis op aarde was. Hahn se opsomming dat dit hier oorwegend gaan oor "... der fir die Gerechten vorherbestimmte Ort" (1998:62) kan nie in die boek na transendentale ruimtes verwys nie, maar na aardse ruimtes, soos die in die omgewing van Jerusalem in 26:1-27:5
} 
strukture soos huise, sinagoges en die tempel). Hierdie ruimtes word telkens binêr hanteer en vorm 'n suborde wat saam met ander subordes, soos dié van die temporele, bydra tot die diakronies gang van die verhaal.

Waar Malbon se ondersoek eerder met die struktuur van die vertelling werk (die vertelstof), gaan Van Eck (1995:71-155) meer narratologies te werk. Hy praat van funksionele ruimte in verhale. Hy onderskei aan die hand van die ondersoeke van Vandermoere, Blok, Ronen, Chatman, Brink en Venter, tussen "setting" en "focal space", toevallige ruimte en bedoelde ruimte. Van Eck (1995:141) kom tot die bevinding dat "space, as focal space, can be seen as symbols used by the narrator to convey his ideological perspective/narrative point on the topographical level of the text". Deur focal space en setting op die vlak van die recit te onderskei, word dit moontlik om agter die verteller se ideologiese perspektief in te kom. Die gestruktureerde ruimte in die mikrososiale wêreld van die vertelling is die metafoor of simbool wat uitdrukking gee aan bepaalde oortuigings, waardes en houdings wat daar in die makrososiale wêreld van die skrywer/verteller bestaan. Die verteller dink na oor sy eie makrososiale wêreld en die van die leser. Dit bring hom by sy bepaalde ideologiese perspektief uit. Hy struktureer daardie perspektief in die wêreld van die teks in en skep vanuit sy alledaagse wêreld 'n mikrososiale wêreld in die teks. Die wêreld waaroor hy nagedink het, is alreeds 'n gevormde wêreld met 'n gangbare simboliese universum. Dis hierdie wêreld wat hy in sy vertelling intolk. "And as the social universe can be seen as a habitualization/structuring of a certain reflection on the symbolic universe, the microsocial world of the text can be seen as the structuring of a certain ideological reflection on that same symbolic universe" (Van Eck 1995:117).

In 'n vertelling soos dié van Markus word geografiese verwysings soos Galilea, Jerusalem, die pad en die tempel as metafore/simbole gebruik om 'n bepaalde begrip van die simboliese universum aan te dui. Dit hoef nie noodwendig te gebeur nie (dit kan bloot net setting vorm) maar dit kan gebeur dat 'n verteller ruimte so struktureer in sy vertelling dat dit die belangrikste simbole word waarmee die ideologiese perspektief oorgedra word. Daar moet telkens nagegaan word of die verteller sy ideologiese perspektief op die topografiese vlak van die vertelling projekteer en, indien wel, hoe hy dit doen. 
Die eiesoortige aard van die ideologiese perspektief wat in die ontleding van apokalipse na vore kom, vereis egter nog een verdere invalshoek. Die pre-moderne perspektief in apokaliptiese literatuur leen hom daartoe om dit ook vanuit bepaalde insigte van die post-modernisme te lees (vgl Venter 1997b). McHale (1987) wys op die moontlikheid om in die literatuur ruimte te konstrueer om "ontological propositions" (McHale 1987:43) te ontgin. In postmodeme literaturteorie word hierna verwys as die "heterotopian space" of "zone" (McHale 1987:45). Anders as in modernistiese literatuur, waar hierdie ruimte geskep word rondom 'n waarnemende subjek of liggaamlose verteller, word hierdie ruimte in postmoderne literatuur tegelyk gekonstrueer en gedekonstrueer. Sonder om te beweer dat apokalipse in geheel postmodernisties gelees moet word, is daar 'n saak daarvoor uit te maak dat kenmerkende trekke van postmoderne tegnieke ook wel in apokalipse voorkom. Deur tegnieke soos jukstaposisie, interpolasie, superponasie en wanvoorstelling, word ruimtes geskep wat in hulle inherente teenstrydigheid die wêreldruimte dekonstrueer en ontologies kommentarieer. Ruimte word in hierdie vertellings die bestaansruimte wat vasgevang sit tussen teenstrydighede. Iets hiervan kom ook na vore in die manier waarop ruimte in apokaliptiese vertellings as dualisties voorgestel word. Ruimte is hier ook vasgevang in die ideologiese stryd tussen God en God se teenstanders. Ruimtes word in die apokalips geskep wat die aardse ruimtes kommentarieer en daaraan 'n ideologiese waarde toeken wat die "verborge waarheid" daarvan bekend maak. Die mikrososiale wêreld van die reisvertelling in die apokalips word dan die simboliese teenhang van die makrososiale wêreld met sy simboliese universum van apokaliptiese denke met al die inherente dualistiese konflik daarin.

\section{DIE BOEK VAN DIE WAGTE}

Die hoofstuk en versindeling van Isaac se Engelse vertaling (1983) word in die ontleding hieronder gebruik. Die vertalings van Charles (1913), Laurence (sonder jaar) en die Duitse vertaling van Uhlig (1984) is ook bestudeer.

Die eerste gedeelte van die Boek van die Wagte, hoofstukke een tot vyf, gaan oor die regverdiges en die goddeloses. Dit is heel moontlik, soos Himmelfarb hier bo beweer het, ' $n$ latere toevoeging tot die boek. Die tweede gedeelte (hoofstukke ses tot elf) stem ooreen met die tema van Genesis 6 van die hemelwesens wat by die aardse dogters reuse 
verwek het. In hierdie gedeelte is moontlik die vroeëre Boek van Noag opgeneem. In hierdie episode word vertel van die besluit van 'n groep engele, hier genoem die "wagte" (vgl Daniël 4:13,17 en 23) om vir hulle aardse vrouens te neem, die reuse wat daaruit gebore is, die ontwrigting wat dit op aarde veroorsaak het, die ander engele wat hulle aankla by God, God se oordeel oor die engele wat oortree het en sy besluit om deur ' $n$ watervloed alles te verwoes, sy begenadiging van Noag (die agterkleinseun van Henog) en die verbanning van Azaz'el en sy trawante na die wildernis tot op die dag dat alles herstel sal word.

In hoofstuk $12 \mathrm{kom}$ Henog vir die eerste keer op die toneel. In drie episodes word van Henog se verskillende reise vertel. Die eerste episode is 'n "reis" na die hemel (1 Henog 12-16) waarin hy God ontmoet en van God bevestiging ontvang dat die wagte wat oortree het, vir ewig verdoem is. Daarop volg twee aardse reise (1 Henog 17-19 en 2036) waarin hy die kosmiese ruimtes leer ken wat God geallokeer het vir die uitvoering van God se besluite. Die vertelling in hierdie drie episodes hoort tot die genre van die reisverhaal. Terwyl die gebeure in al drie episodes wêreld-analogies en sekwensieel verloop, die karakters redelik stereotiep is en die intrige 'n baie lae profiel handhaaf, is die ruimte telkens baie funksioneel en vorm dit telkens die fokusruimte. Die funksionaliteit daarvan word telkens bepaal deur die verhouding waarin dit tot die ander komponente van die verhaal staan. Om dit uit te lig gee ek vervolgens afsonderlik aandag aan elkeen van die drie episodes.

\subsection{Die hemelse reis: God se onveranderlike besluit (1 Henog 12:1- 16:4)}

Hierdie episode bestaan uit vyf tonele:

Die engele stuur Henog na die aarde (12:1-6);

Henog by die wagte op aarde (13:1-6);

Henog ontvang ' $n$ visioen by Dan (13:7-8);

Die finale oordeel oor die wagte (13:9-14:7);

Die inhoud van die visioen (14:8-16:4). 
Die plot in hierdie episode is baie eenvoudig. Die engele in die hemel stuur vir Henog (die helper) na die aarde om die oordeel wat God gevel het (die objek) oor die wagte aan hulle oor te dra (die ontvangers). Die intrige verhoog wanneer die wagte probeer om die vonnis af te weer (teenstand) deur Henog te oorreed om vir hulle by God in te tree. In 'n visioen besoek Henog egter die hemel en ontvang van God self die finale bevestiging dat die besluit onomkeerbaar is. Die plot ontknoop wanneer Henog na afloop van sy visioen aan die wagte oordra dat daar geen begenadiging vir hulle sal wees nie.

Die laaste toneel, die visionêre "hemelreis" van Henog (14:8-16:4), vorm 'n metadiëgetiese narratief in die episode. Dit keer uitvoerig terug na die voorafgaande derde toneel waar daar deur die tegniek van versnelling 'n gap in die vertelling geskep is deur slegs kursories te verwys na 'n visioen wat Henog by die waters van Dan ervaar het. Die flash back in hierdie toneel plaas Henog se hemelreis in die fokuspunt van die episode. Dit gee 'n hemelse en Goddelike gesagsdimensie aan die boodskap wat Henog moes oordra aan die wagte wat oortree het.

Hierdie effek word in die vertelling verkry deur disparaatheid tussen vertelde tyd en verteltyd, maar veral tussen vertelde ruimte en vertelruimte. Veral deur die tegniek van interpolasie word hier in McHale se terminologie a "heterotopian space" of "zone" (McHale 1987:45) geskep.

Daar word in die verteltyd teruggekeer na die vorige gebeure van die visioenervaring. Die ervaring word nou uitvoerig vertel deur veral 'n omvattende ruimtebeskrywing wat aan die afloop van die episode en die ontvouing van die verhaal ' $n$ bepaalde ideologiese perspektief gee. Daardie perspektief word in die fokusruimte uitgebou deur die manier waarop die hemelruimte waarin Henog in sy visoen beweeg, geskets word. Die verteller laat ruimtebeelding en dialoog in hierdie toneel baie sterk op mekaar inspeel.

Vir sy ruimtebeelding maak hy gebruik van die kategorie wat Malbon "argitektoniese ruimte" sou noem. Die ruimte word beskryf in terme van konstruksies (mure, huise, vloer, plafon), boumateriaal (marmer, mosaïek, kristal) en natuurelemente (weerlig en vuur). Dit is veral die herhaaldelike beskrywing van dit wat hy tydens sy hemelse reis sien in terme van vuur (tonge van vuur, strome vlammende vuur en groot vuur) wat aan die vertelruimte hier disparaatheid met die alledaagse ruimte gee. Hoewel Himmelfarb 
moontlik reg is om hierdie ruimte as analoog aan die aardse tempel te sien en die moontlikheid selfs bestaan dat die hemelse ruimte hier as model vir die aardse tempel gesien kan word, is dit hierdie beskrywing van dinge in terme van flikkerende vuur (nie in terme van hitte nie, maar in terme van gloeiende voorkoms) en die emosionele ervaring daarvan wat daaraan 'n ideologiese perspektief gee.

Hierdie ruimte word volledig met God geassosieer as God se tuisruimte. Dit ondersteun die karakterbeelding van God as Heer van alles, Koning van die heelal, die Heilige en Groot Een en die Skepper. Vir die besoeker Henog, hoewel hy in toneel 1 voorgehou word as medebewoner van die ruimtes van die engele en die heiliges, is hierdie ruimte vreemd en skrikaanjaend. Dit is God se magsruimte van waaruit God besluit oor die lot van die wagte wat oortree het en waar God vir Henog bevestig dat die besluit onomkeerbaar is. Tog is dit die ruimte waartoe hy toegang het en waarvandaan hy gestuur word om as skrywer van geregtigheid en as hemelse boodskapdraer op te tree.

Dit is veral in die lig van die dialoog in die vyfde toneel, dat die funksie van die ruimtes in hierdie episode duidelik word. Dit is nie net ruimtes wat iets oor die karakters van die vertelling sê nie, maar wat funksioneel ingespan word om iets oor die verhouding tussen hemel en aarde en die boosheid op aarde te sê. Die temas word weer eens herhaal dat die wagte oortree het, dat hulle die hemel verlaat het, dat hulle iets boos op aarde aan die gang gesit het en dat daar vir hulle geen vrede sal wees nie. Dit is egter die afgrensing tussen hemel en aarde wat hier op die spits gedryf word. Die hemelwagte het hulle hemelstatus permanent verbeur en daar is geen terugkeer vir hulle moontlik nie. Hulle is vir altyd na die aarde verban. Deur hulle toedoen het daar op aarde bose geeste gekom en sit die aarde vasgevang in die greep van die komupsie en ellende wat hulle op aarde gevestig het.

Henog het die wagte wat oortree het op 'n bepaalde plek ontmoet: Lesja'el tussen Libanon en Sanser. Dit is die plek waar hulle hulle oordeel aanhoor en vreesbevange vir Henog vra om vertoë tot God te rig omdat hulle voortaan "nie meer kan praat of hulle oë na die hemel kan oplig" nie (13:5). Die geopolitiese ruimte van Lesja'el is vir die gevalle wagte 'n aardse ruimte van oordeel en krisis waarvan hulle nooit weer sal loskom nie. Teenoor hierdie krisisruimte staan die geografiese ruimte van die waters van Dan, ten suidweste van Hermon (13:7), waar Henog sy visioen ervaar. Dit is 'n aardse ruimte van 
waar Henog visionêr na die hemel reis en sy inligting oor die finale lot van die wagte en hulle permanente aardgebondenheid ontvang. Dit is 'n openbaringsruimte wat verwyderd van die benoemde krisisruimte van die wagte staan. Soos Bet-El in Genesis 28 , is dit 'n poort na die hemelse openbaring van die veroordeelde wagte en die finale oordeel. Dit word ook die vertrekpunt van waar Henog vertrek om die finale oordeel by Lesja'el uit te spreek. Van daar af onderneem hy in ' $n$ volgende episode 'n aardse reis in geselskap van die engele na die plekke op aarde wat aan die bose geeste toegewys is.

So word Henog se reis een na esoteriese wysheid oor die lot van goed en kwaad, hemel en aarde, kosmos en hel. Vanuit sy reiservaring word dit 'n ontdekking van die waarheid van hemel en aarde, 'n ontologiese kommentaar op die aardse ruimtes wat vasgevang sit in die dualistiese stryd tussen God en God se teenstanders, die hede en die toekoms, die hemel en die aarde, die goed en die kwaad. Die mikrososiale wêreld van sy reiservaring word die vertelde uitbeelding van die makrososiale wêreld van die simboliese universum van die apokaliptiese siening van die outeur(s).

\subsection{Die eerste aardse reis: Henog vind uit waar die wagte gevange gehou word (1 Henog 17:-19:3)}

Die plot van hierdie episode kan in die terme van Chatman as 'n plot of revelation beskryf word. Die plot word episodies oor sewe tonele ontvou. Henog is aktansieel die ontvanger wat van plek tot plek beweeg en deur die engele gehelp word om dit wat hy sien, te verstaan en sy onkunde te besweer. In Crane se terme is dit 'n plot waarin daar verandering van kennis intree. Die ontvouing van die intrige is verwoord in Henog se bevinding: "net ek het die visioen van die einde van alle dinge gesien en geen menslike wese sal sien wat ek gesien het nie" (19:3). Hy het 'n openbaring ontvang en op sy reis 'n greep gekry op esoteriese wysheid.

Die klem val egter nie op die karakters of die geïntegreerde ontwikkeling van gebeure nie, maar op die ruimte. Alhoewel Henog sê dat hy die einde van alle dinge gesien het, is hier geen inligting oor die chronologiese verloop van sake of die tyd van die einde nie. In sy reiservaring word alles beskryf in terme van aardse kosmiese ruimte. Henog reis van een ruimte na 'n ander. Hy neem telkens dinge waar en leer die betekenis daarvan verstaan in terme van God se funksionele allokering van aardse ruimtes, veral ten 
opsigte van sy oordeel oor die wagte wat oortree het. Die episode is 'n vertelling van openbaring wat in terme van aardse ruimtes plaasvind. Die einde van alle dinge (eskatologie) word geopenbaar op ruimtelike-kosmologiese vlak.

Die ruimte in die vertelling vorm 'n "zone", 'n fokusruimte. Dit kan gesien word in die uitbeelding van die karakter van Henog wat bykans uitsluitlik in terme van "beweeg" en "sien" (18 keer) gedoen word en geheel op die sigbare toneel gefokus is. Dit is ook duidelik in die gedramatiseerde vertelling wat intradiëgeties die een toneel na die ander deur Henog se oë beskryf en die hoorder kognitief lei om die ruimtes vanuit 'n bepaalde ideologiese perspektief te sien. Dit kom ook na vore in Henog se aksies. Hy word by herhaling "opgelig" en deur die engele na plekke gebring. Hy beweeg soos 'n bo-aardse wese oor die hele aarde en beskou telkens die toneel van bo af. Hy besoek telkens ongewone plekke waar gewone sterflinge nooit kan kom nie. Ook die rolle van die ander karakters is op die ruimte gefokus. Die hemelwesens stel hom in staat om die ongewone plekke te besoek. Hulle vergesel en ondersteun Henog om op die verskillende tonele te fokus. Uriël stel Henog in staat om die toneel vanuit 'n esoteriese perspektief te sien. Dit alles koppel ' $n$ bepaalde ideologiese betekenis aan die ruimtes.

Elkeen van die sewe tonele werk met kosmiese ruimtes wat topografies beskryf word. Dit is telkens ' $n$ ander gebied op aarde wat in terme van berge, riviere, see, winde en weerligte geskets word. Wat opval, is hoe hierdie topografiese ruimtes soms metafories-argitektureel beskryf word as "kamers" van lig en donker, "stoorkamer" van die winde, "hoeksteen" van die aarde, "pad" van die engele, "pilare", "gevangenis" en "fondament" van die aarde. Poëtiese taal word deurgaans getriuik, veral om die toneel in terme van vuur, lig en duisternis te beskryf.

Terwyl die tonele binne die ruimte van poëtiese taal herkenbare ooreenkoms met die alledaagse vertelde ruimte het, is dit veral die ruimte in tonele ses en sewe wat disparaat met die alledaagse ruimte staan. Dit is ook hierdie ruimte wat deur die engel Uriël vir Henog verklaar moet word. Die ruimte in toneel een (17:1) is 'n ongespesifiseerde ruimte waar die engele verkeer. Die nuimte in die daaropvolgende tonele herinner aan die kosmiese beskrywings in Job $28: 20-28$ en $36: 24-33$. Toneel 2 (17:2-3) is die blyplek van die orkaan en die weerlig bo-op die berge. Die ruimte in toneel $3(17: 4)$ is die plek in die weste waar die son bloedrooi oor die see ondergaan. Dit word in toneel 
4 (17:5-6) vereenselwig met die donker plek in die weste waarheen alle riviere vloei en waarheen die dooies gaan. Die kosmiese ruimte in toneel $5(17: 7-8,18: 1-5)$ is in ooreenstemming met die wêreldbeeld van die tweede eeu v $C$ ' $n$ wêreld wat op pilare staan, deur 'n hemelgewelf oorkoepel word en deur wind, wolke en sterre omvou word. Die ruimte in die sesde toneel (18:6-16) staan in die fokuspunt van die reisbeskrywing in hierdie episode. In die suide (Uhlig 1984:548)/weste (Isaac 1983:23) besoek Henog 'n toneel van ses (vgl Uhlig 1984:548)/sewe (vgl Isaac 1983:23 en Laurence sa;) berge. In die middel van hierdie berge is daar ' $n$ eensame plek, ' $n$ diep put/waterfonteine en reg daarbo 'n plek wat geen fondament daaronder of hemel daarbo het nie. In toneel 7 (19:1-3) verklaar Uriël vir Henog dat hierdie plek die gevangenis is waar God die gevalle wagte aanhou tot op die dag van oordeel.

Die vertraging in die tempo van die verteltyd by tonele ses en sewe aksentueer die ruimte wat daar gebruik word. Die plek tussen die berge toon ooreenkoms met die hemelse toneel in die vorige episode. Die berg wat in die lug opwaarts reik, word nie net met die troon van God vergelyk nie, maar dieselfde beelde van marmer, saffier en vlamme word weer gebruik. Ook wanneer die afgrond beskryf word met die ruimte wat in suspensie daarbo hang, sonder basis of bokant, en dit as 'n vreeslike plek beskryf word waarin sewe sterre, soos berge wat brand, gehou word, word dit met die hemelse mag van God in verband gebring. 'n Naamlose engel beskryf die ruimte as die gevangenis vir die sterre wat versuim het om betyds uit te kom en God se wet oortree het.

Die engel Uriel beskryf die plek in die volgende toneel (19:1-3) as die blyplek van die wagte wat met die mensevrouens oortree het en in baie gestaltes kan verskyn. Hulle sal daar bly tot op die dag van die finale oordeel. Die plek waar hemel en aarde ontmoet, waar die aanwesigheid van God deur vuur aangedui word, is ook die plek wat God uithou om die hemelwesens wat oortree het, gevange te hou tot op die dag van oordeel. Soos God an bepaalde ruimtes bepaalde kosmiese funksies toegedeel het, soos dat dit die plekke van oorsprong is van die riviere van die wêreld, die blyplek van die winde, die oorsprong van die weerligte of die plek waar die son ondergaan, so het God ook kosmiese plek gegee op arde aan die hemelwesens wat teen God oortree het. En dit is die plekke waarop Henog afgekom het en waarvan net hy weet. 
Henog se reis deur die kosmiese ruimtes van God se skepping bring hom ruimtelik uit by God se beslissing oor die hemelse wagte wat verderf op die aarde gebring het deur hulle oortreding. Die beslissing word aan hom geopenbaar in ruimtelike eerder as temporele terme. In die skrikaanjaende eensame ruimte waar hemel en aarde ontmoet, kom hy op die snykant van God se oordeel oor die boosheid af.

In aansluiting by die vorige episode waar Henog deur sy hemelreis bevestiging van God self ontvang het dat die wagte gedoem is tot verblyf op aarde vir altyd, ervaar hy in hierdie aardse reis die openbaring van hulle aardse blyplek. Sy openbaring gee uitdrukking aan die kognitief-ruimtelike apokaliptiese perspektief van die verteller wat die oorsprong van die kwaad in terme van 'n intrige tussen God en hemelwesens sien wat oortree het en tot die gevangenis van ' $n$ bepaalde aardse ruimte ingeperk is.

\subsection{Die tweede aardse reis: Henog ontdek die betekenis van die kos- miese ruimtes (1 Henog 20:1- 36:4)}

In hierdie episode word die tendens van die vorige episode voortgesit, maar op nog omvangryker skaal. Meer aardse ruimtes kom aan die bod en nog meer figure word betrek in die dualistiese toedeling van ruimtes in ooreenstemming met die oordeel of seën van God. Die episode bestaan uit 15 tonele:

- 'n Lys van engele waarvan sommige Henog vergesel (20:1-7);

- 'n Chaotiese plek wat sewe sterre gevange hou (21:1-6);

- 'n Plek wat nog vreesliker is waar die engele gevange gehou word (21:7-10);

- 'n Hoë berg in die weste met hol plekke waar die geeste van die dooies bly (22:1-14);

- 'n Plek aan die einde van die aarde in die weste waar die hemelliggame gestraf word $(23: 1-4)$

- Sewe berge met God se troon en 'n groot geurige boom (24:1-25:7);

- Die sentrum van die wêreld met die heilige berg en 'n vervloekte vallei waarin die vervloektes bly wat teen God gelaster het (26:1-27:5);

- 'n Berg in die wildernis in die ooste (28:1-3); 
- Die onwelriekende boom van oordeel in die wildernis en die welriekende kaneelboom (29:1-30:3a);

- Die berg met alwyne op (30:3b- 32:1);

- Die tuin van geregtigheid en die boom van wysheid in die ooste (32:2-6);

- Die oostelike uiteinde van die aarde met die hemelpoorte (33:1-4);

- Die noordelike uiteinde van die aarde en die drie oop hemelpoorte waardeur die koue en hael inwaai (34:1-3);

- Die westelike uiteinde van die aarde en drie oop hemelpoorte (35:1);

- Die suidelike uiteinde van die aarde met die oop poorte en die hemelse poort (36:14).

Die verhaalinhoud van hierdie episode is aan die skraal kant. Die klem val eerder op karakterbeelding en veral ruimtebeelding. Die tonele word almal saamgebind deur die sentrale figuur Henog wat telkens "kom" en "sien". In elke toneel kom hy by 'n plek aan, neem dit waar en gee ' $n$ beskrywing daarvan en ook 'n verklaring. Soos die vorige episode vind daar 'n verandering in kennis plaas en kan daar van 'n openbaringsplot gepraat word. Die onderliggende intrige van die vertelling is die ongehoorsaamheid van verskillende wesens, soos sterre, engele en mense, en God wat hulle straf deur hulle tot bepaalde kosmiese ruimtes in te perk.

Die ruimtebeelding in die vertelling is kwasi-mimeties: dit word in terme van die alledaagse beskryf (berge, vuur ens) maar telkens in scenarios wat verwyderd staan van die alledaagse werklikheid en eers verduidelik moet word. Die ruimte in tien van die tonele funksioneer eksplisiet simbolies en kan net binne die vertelling self verstaan word. Voorbeelde van benoemde ruimtes wat simboliese betekenis dra, is "die heilige plek" $(25: 5,6)$, "'n heilige berg" (26:2), "die sentrum van die aarde" (26:1), "die geseënde land" (27:1), "vervloekte vallei" (27:1), "die boom van oordeel" (29:2) en "die tuin van geregtigheid" (32:3). Die ruimtes wat gebruik word, is oorwegend topografiese ruimtes (berge, see, vallei, ens) wat nie benoem word nie (met uitsondering van die Erutrese See) en slegs met windrigtings aangedui word ten opsigte van hulle ligging op aarde. Strukturele ruimtes word wel ook gebruik (huis van God in 25:5, troon van God in 25:25 en poorte van die hemel in 33:2), maar dit is in die minderheid. Wat oor die algemeen gebeur is dat die vertelling aan elke ruimte ' $n$ bepaalde waarde toeken. Die waarde word 
bepaal in terme van die goeie of slegte verhouding tussen God en die wesens wat God gemaak het.

Die karakterbeelding in die episode ondersteun die tendense in die ruimtebeelding. Die aksies van Henog word oorwegend uitgedruk in terme van "kom" (17 keer) en "sien" (28 keer), maar ook in terme van "reageer", "antwoord", "vra" en "loof". Sy bewegings belig telkens die betekenis van 'n bepaalde plek. Die herhaling van Henog wat God loof, neem tematiese omvang aan en maak deel uit van die waardetoekenning waarna reeds verwys is. In 22:14 loof hy God as die God van geregtigheid wat vir ewig heers. In 25:7 loof hy God as die ewige God wat dinge vir die regverdiges geskape en vir hulle gegee het. In 27:5 loof hy God as die Een aan wie die eer toekom. In 36:4 loof hy God wat groot dade gedoen het vir die engele en vir die mense sodat hulle God se heerlikheid kan aanskou en God vir ewig kan prys oor wat God gedoen het. Die eerste drie van hierdie lofprysings volg direk nadat 'n engel vir hom die betekenis van 'n bepaalde ruimte uitgespel het.

Henog word deurentyd vergesel van engele wat dinge vir hom uitwys, praat en veral antwoord op sy vrae. Hoewel hulle verskillende name het, wat in breë trekke ooreenstem met die lys van engele in hoofstuk 20, tree hulle almal presies dieselfde op. Hulle vergesel Henog op sy reis oor die aarde en help hom om op kosmiese skaal te ontdek wat die funksie van die verskillende plekke is, veral as blyplekke vir wesens wat teen God oortree het en daar aangehou word in afwagting op die finale oordeel. Die verskillende dialoë tussen Henog en een na die ander engel, skep vertraging in die verteltyd waarin daar kommentaar gelewer word op die plek waarna Henog kyk. Dit is elke keer 'n simboliese uitleg van die betekenis van die bepaalde toneel. Hierdie kommentaar op die ruimte en gevolglik die betekenis daarvan, word sodoende geaksentueer en onderstreep die toneel as ' $n$ belangeruimte.

Die wyse waarop Henog geskets word as reisiger, waarnemer, vraer en ontvanger van antwoorde, dien as instrument vir die verteller om sy bepaalde perspektief op die aardse ruimtes te stel. Eweneens dien die wyse waarop die engele vertel word as wesens wat op Henog gerig is, wat hom lei, sake vir hom uitwys en veral op sy vrae antwoord met esoteriese kennis, op die vertellersperspektief van toegedeelde kosmiese ruimtes. Hierdie perspektief is in ooreenstemming met die verhouding tot God en God se besluite 
oor die wesens wat God geskep het. Sterre wat oortree het, engele wat in detensie gehou word, die geeste van dooies wat wag op die oordeel, hemelliggame wat aanhoudend brand, vervloektes wat in 'n vervloekte vallei aangehou word en natuurelemente, diere en voëls, word almal aan een of ander kosmiese ruimte toegeken, volgens hulle oortreders teen God of sy begenadigdes is.

Veral die sewende toneel (26:1-27:5) is van besondere belang om hierdie episode te verstaan. Die toneel speel af in wat bestempel word as die sentrum van die wêreld (Jerusalem, volgens Isaac 1983:26, se vertaleropskrif). Dit is 'n geseënde plek met 'n heilige berg en verskillende ander berge en valleie. Te midde van die toneel is daar egter ook 'n diep en droë vallei wat vervloek is. Hierin bly die vervloektes wat teen God gelaster het en God se eer misken het. Hulle word hier versamel en sal hier geoordeel word op die laaste dag. Hulle word ook in kontras gestel met die regverdiges wat God prys en God op die dag van oordeel sal loof vir God se genade wat aan hulle betoon is. Dieselfde aarde en dieselfde toneel is dus bevolk met oortreders sowel as begenadigdes. Aan elkeen van hierdie twee soorte word 'n bepaalde ruimte toegeken waar hulle sal bly tot op die dag van die finale oordeel. Net soos in die episode van sy hemelreis word ruimtes onderskei in die wat toegedeel is aan veroordeeldes en die wat toegesê is aan die regverdiges.

Op sy reis in hierdie episode ontvang Henog dus deur openbaring die esoteriese wysheid van God se toewysing van die kosmiese ruimtes. Dit bring by hom verwondering, verbystering en aanbidding. Deur perseptuele fokalisasie, wat veral in terme van ruimte ervaar word, word die ideologiese faset uitgebou wat alle aardse ruimtes laat funksioneer in terme van die dualistiese verhouding met God en die gevolge daarvan. Sy reis is ' $n$ reis oor die ruimtes van die aarde, 'n reis in die beslissing van God oor die gehoorsame en ongehoorsame wesens van die aarde en waar hulle bly. Dit is bevoorregde kennis wat hy ekslusief op sy reis opdoen. God se beslissingsmag word aan hom geopenbaar in terme van die ruimtes wat God aan elkeen toegeken het in afwagting op die finale oordeel in die laaste dag. 


\section{DIE BETEKENIS VAN HENOG SE REISE}

Die drie reise van Henog sluit tematies baie nou aan by die inleiding van die boek (1 Henog 1-5). Dit gaan oor God se oordeel en die gevolge daarvan ${ }^{2}$. In teenstelling tot die hemel waar die hemelliggame nie buite hulle bane beweeg of van hulle opdragte afwyk nie (1 Henog 2:1-5:3), is daar op aarde wesens en mense wat van die regte pad afgewyk het. Vir die regverdiges wag daar seën, maar vir die wat oortree het, wag die eindoordeel van God.

Ook in die res van die Boek van die Wagte duik hierdie tema telkens op. Soms word die tema uitgebrei en soms dien dit as agtergrond vir ander temas. In die drie reise in 1 Henog 12-36 word hierdie tema met reisverhale uitgebeeld. Wat veral belangrik is daarin is die funksionaliteit van die ruimte. Soos in 1 Henog 41:1-44:1; 52:1-56:4; 59:160:16; 93:11-14 en 100:10-101:9, word eietydse kosmologiese kennis ${ }^{3}$ gebruik in die vertelling. Thom (1983:44) merk tereg op dat alles wat Henog op sy reise ervaar "... has either a cosmological or an eschatological significance, and in most cases both". Hoewel Milik meen dat hier na werklike plekke verwys word, is Rowland van oortuiging dat op uitsondering van Jerusalem na, hier nêrens na enige bekende plek verwys word nie. Hier is ' $n$ ".. absence of references to familiar places in the world" (Rowland 1982:124). Daar word verwys na daardie onbekende dele van die wêreld waarvan “... normal perception of the universe would not be able to give any information" (Rowland 1982:124). Die materiaal wat hier voorkom word eerder gebruik "... for religious reasons" (Rowland 1982:124) en met “... eschatological significance” (Rowland 1982: 125). Die kosmologiese materiaal in hierdie dele is telkens funksioneel verbind aan die eskatologiese hooftema: “... cosmology undergirds eschatology" (Nickelsburg 1991:97).

2 Rowland (1982:93) oordeel dat die verhale in 1 Henog 14-36 "... do not appear to be intended to function as an explanation of the problem of evil in their present context". Dit gaan volgens Rowland eerder oor die kontras tussen die engele wat God se geheime wederregtelik openbaar en Henog wat deur God se besluit die hemelse gebeime leer ken. Hierdie siening verklaar egter nie hoekom daar 'n binêre verdeling is van aardse ruimtes tussen die wat as strafplekke en die wat as bewaarplekke geoormerk is nie. Vergelyk en kontrasteer ook my bevinding oor die eerste hemelreis (1 Henog 12:1-16:4) hier bo by 4.1 .

3 Die grafiese voorstelling wat Malina (1995:166) op grond van Milik en Grelot maak van die kosmiese beeld van Henog, is interessant, maar onvoldoende. Dit gaan in die Boek van die Wagte juis oor die betekenis wat aan die verskillende aardse ruimtes geheg word en nie om die bepaalde plekke op hulle eie nie. 
Die mikrososiale wêreld van Henog se reise bestaan uit die hemelse en kosmiese ruimite wat uitgekarteer is volgens die eindoordeel van God oor alle geskape wesens. Henog se hemelreis ${ }^{4}$ bring hom by God uit en sy finale besluit dat die wagte vir altyd op aarde sal bly. Sy eerste reis oor die aarde bring hom by die plekke uit wat God aan die natuurelemente toegesê het, maar ook by die plek ${ }^{5}$ wat God as gevangenis vir die oortredende wagte uitgehou het. Tydens sy tweede aardse reis word an Henog al die plekke geopenbaar wat God aan die oortreders toegeken het, sowel as die plekke wat God vir die gehoorsames geallokeer het. Die toegekende ruimte is telkens die "heterotopian zone" (McHale) waarop die verteller sy apokaliptiese ideologie projekteer. Die betekenis van elke ruimte word bepaal deur die binêre opsie van die straf van God of die seën van God. Soos die skeppingsordinansie aan elke natuurelement sy vaste plek toegeken het, word elke kosmiese ruimte, selfs dié wat geen mens voor Henog nog ooit gesien het nie, volgens die vaste besluit van God, 'n gevangenis of bewaarplek vir die eindoordeel.

Dat hierdie hantering van ruimte in die mikrososiale wêreld van die reisvertelling die wêreldruimte van die makrososiale wêreld van die outeur en sy simboliese universum dekonstrueer en ontologies kommentarieer, blyk uit verskeie dinge. Henog ontvang 'n eksklusiewe openbaring wat hom nie net laat sien wat geen ander mens gesien het nie, maar wat hom ook dinge vanuit ' $n$ bepaalde hoek laat insien soos geen ander mens nie. Hy leer kyk na die plekke waar hy reis vanuit die hoek van ruimtes wat vasgevang sit in die dualistiese stryd tussen God en sy teenstanders, die hede en die toekoms, die hemel en die aarde, die goed en die kwaad. Ruimte is in hierdie reisvertellings die bestaansruimte wat uitgelewer is aan een van twee teenstrydighede. Wanneer die inligting aan hom oorgedra word deur die hemelwagte wat getrou gebly het en hom aan die begin uitgestuur het teen die wagte wat oortree het, word dit boonop duidelik wat die openbaring vir

\footnotetext{
4 Stone (1978:489) wys daarop dat “... the early Merkabah-type ascent contemplation must be accepted as part of Judaism from its oldest extra-biblical literature on".

5 Stone (1978:486) se beskrywing van hierdie nimtes as "underworld" en "Sheol and the Underworld", is nie korrek nie. Dit gaan oor die kosmiese ruimtes op aarde en nie die onderwêreld nie. In 18:6-16 gaan dit oor 'n ruimte wat niks daarbo en niks daaronder het nie. Vervloekte en geseënde ruimtes staan direk langs mekaar in die "sentrum van die wêreld", soos dit in toneel sewe (26:1-27:5) in episode drie (1 Henog 20:$36: 4$ ) beskryf word. Rowland (1982:92) wys daarop dat die "place of darkness" gewoonlik deel is van die hemelse wêreld in apokalipse en dat dit uitsonderlik is dat hier na die "underworld of punishment" verwys word as ' $n$ aardse ruimte los van die hemele. Sy beskrywing daarvan as 'n onderwêreld is egter in feite nie korrek nie, omdat dit ' $n$ aardse ruimte is wat op dieselfde horisontale vlak lê as die res van die ruimtes in die Boek van die Wagte.
} 
Henog inhou. Hy ontvang nie net in terme van ruimtelike toedeling die inligting oor die finale oordeel oor die hemelwagte wat oortree het nie, maar ook die versekering van God se besluit oor alle wesens op aarde wat teen God oortree het. Tegelykertyd ontvang hy ook in ruimtelike terme die bevestiging dat dié wat aan God getrou gebly het, hulle plek sal hê op die aarde. Dit voer hom in die derde episode tot die uitgebreide tema van lofprysing vir God wat na die gelowiges omsien.

Die mikrososiale wêreld van binêre ruimtelike hoop of verdoemenis, projekteer op die makrososiale wêreld van die verteller die ideologie van 'n apokalipties simboliese universum wat nie soseer in chronologiese terme funksioneer nie, maar veral in ruimtelike terme dink oor die kosmos en die eindbestemming van alle kreature. In 'n wêreld waar goed en kwaad langs mekaar staan, kwaad wat in die verlede gedoen is teenoor bevryding wat in die toekoms verwag word, aarde in spanning met die hemel, kom die apokaliptiese versekering van 'n bevryding in terme van 'n kosmos waarin elke ding 'n spesifieke plek het, elke oortreder 'n gevangenis en elke getroue gelowige 'n plek van bewaring totdat die eindoordeel aanbreek.

\section{DIE APOKALIPTIESE BEWUSSYN}

Oor die makrososiale wêreld van die werklike verteller uit die laat derde, vroeg tweede eeu v C is nie baie bekend nie. Oor hierdie trajek van apokaliptiese denke waarin die ruimtelike dimensie belangriker was as die temporele kan slegs in breë terme geteoretiseer word. Dit kan alleen binne 'n breër raamwerk gedoen word.

Die hantering van 'n dualistiese wêreldbeskouing op 'n ruimtelike vlak eerder as op 'n temporele vlak, is volgens Nickelsburg (1991:63) deur wysheidskringe beïnvloed: "The Enochic authors provide this spatial axis, in large part by using material from the 'wisdom tradition' and shaping and nuancing it to serve the eschatological character and purpose of the temporal axis". Profetiese temporele dualisme, ruimtelike belange van die wysheid in die orde van die $\operatorname{kosmos}^{6}$ en mitologiese ontologiese dualisme het hier ineengevloei om 'n unieke konstruksie van die werklikheid te skep.

\footnotetext{
6 Hiermee word nie bedoel Gerhard von Rad se standpunt dat wysheid die matriks is waanuit apokaliptiese literatuur ontstaan het nie. Ook word nie gedink in terme van J J Collins (1997:227) dat apokaliptiek 'n vorm van wysheid is nie. Hier word gewoon bedoel dat apokaliptiese denke die gedagte oor kosmiese orde van die wysheidsdenke oorgeneem het in 'n ontologiese uitspraak oor die wêreldruimte.
} 
Nickelsburg se beskouing dat die wysheidstradisie 'n rol gespeel het, kan aanvaar word $^{7}$. Dit sal egter meer genuanseerd hanteer moet word. Die rigting waarin die wysheidstradisie beweeg het, is beïnvloed deur die gebeure van 312 tot $198 \mathrm{v}$ C toe Palestina deel gevorm het van die Ptolemese ryk. 'n Egiptiese vorm van Hellenisme ${ }^{8}$ het sterk invloed uitgeoefen op die Joodse denke. In die kruiskulturasie en kruisbeïnvloeding van denke het ' $n$ bepaalde konseptualisering van kosmies bepaalde tyd en kosmiese ruimtelike orde plaasgevind (vgl Venter 1996:613-616 en 623). Die gedagte van kosmies bepaalde tyd staan in die eerste boek van Henog nog in 'n baie vroeë stadium van ontwikkeling en is beperk tot 'n onbepaalde eskatologiese tyd van oordeel. Eers in die latere Visioen van die Diere (1 Henog 85-90) en die Apokalips van die Weke (1 Henog 93:110) kom 'n uitgewerkte berekening en periodisering van die tyd voor.

Die kosmiese ruimtelike orde word egter hier uitgewerk op 'n omvangryke skaal. Die aardse ruimtes vervul nie net die rol wat God daaraan by die skepping gegee het nie, maar het nou ook heilswaarde in terme van God se eindoordeel oor alle kreature. Dit word bekend gemaak in 'n openbaring oor die toekoms en veral "... the remote places in the cosmos, where the reality and promise of salvation lie hidden" (Nickelsburg 1991: 51). Die outeur/s van die Boek van die Wagte konsentreer op die ruimtelike dimensie, op 'n wêreld wat ervaar kan word deur menslike sintuie. Terwyl hierdie ruimtes nie nader gespesifiseer word nie, is die ruimte gesetel "... in the authors" cosmology and mythic geography, and in their references to nonanimate aspects of creation" (Nickelsburg 1991:55). In aansluiting by die siening van orde in die wysheid “... the authors emphasize the orderliness and obedience that prevail in this spatial and material realm" (Nickelsburg 1991:55).

Die apokaliptiese oortuiging dat daar 'n diepliggende orde in die kosmiese ruimte is, hang enersyds saam met die konsep van heiligheid en andersyds saam met die bepaalde millenniaristiese perspektief van die outeur/s. Volgens die breër ideologiese

7 Thom (1983:46) redeneer dat hier wysheidsinvloed is omdat dit hier gaan oor $\mathbf{n}$ kosmologiese orde wat God geskape het. Hy verbind kosmos en wysheid op grond van die aanwesigheid van die twee wysheidstemas van vergelding en Wetsgehoorsaamheid.

$8 \mathrm{~J} \mathrm{~J}$ Collins (1997:231) wys op die invloed wat Hellenistiese denke op die Judese wysheid gehad het in, byvoorbeeld, die oortuiging van 'n hiemamaals "... (that) had been popularized in Judaism by the apocalyptic writers". Hellenisties beinvloede wysheidsdenke en apokaliptiese denke het op hulle beurt ook weer op mekaar ingewerk en standpunte soos die in Henog bewerkstellig. 
raamwerk van die Judese gemeenskap was heiligheid die sluitsteen van die Jodedom (vgl Venter 1996:613-616). Binne die strukture van suiwerheid en besoedeling moes daar naas sosiale en liggaamsgrense ook kosmologiese grense wees. Die Egipties-beìnvloede wysheid het die Judeërs van daardie tyd in staat gestel om in hulle klassifikasie van heilige sake ook die kosmologiese grense te trek van heilige teenoor besoedelde plekke op aarde. Profetiese temporele dualisme het wel hierin 'n rol gespeel, soos Nickelsburg (1991) aangedui het. Dit was egter veral die heiligheidskonsep wat 'n rol gespeel het in die klassifikasie van aardse ruimtes binne die binêre opsies van vervloekte of geseënde plekke, gevangenis vir ongehoorsame veroordeeldes of bewaringsplekke vir gehoorsames.

Die behoefte vir die versekering dat daar wel orde is en dat daar ruimte aan goddeloses en getroue gelowiges in die hemel toegeken is, spruit moontlik uit die millenniaristiese krisis van die laat derde, vroeg tweede eeu v C (vgl Venter 1996:619-623). Dit is nie moontlik om presies te bepaal van waaruit die ervaring van veronregting of gevoel van ontneming gespruit het nie. Dit kon moontlik iets te doen gehad het met politieke of finansiële vervreemding, of met die herdeling van grondgebied, of 'n skuif in geografiespolitieke mag. Thom (1983:47) meen dat dit bloot te doen het met “... the general suffering and chaos which characterized the third and early second century". As die geneigdheid na die aktivistiese Makkabese posisie in die Hasidies/Esseense Boek van die Droom Visioene (1 Henog 83-90) in ag geneem word (vgl Venter 1997a:80-83 en 88-90), lyk dit baie moontlik dat dit ongelukkigheid op die polities-religieuse terrein was. Wat ook al die presiese oorsaak was, is die kwaad ervaar as eksterne mag en die enigste verweer daarteen was die apokaliptiese versekering dat daardie mag hokgeslaan sal word binne die kosmiese grense wat God daargestel het. 'n Antwoord van apokaliptiese versekering van orde en heiligheid in terme van kosmies geografiese ruimtes, moes op een of ander wyse korreleer met die aard van die bepaalde krisis wat ervaar is.

Die persoon of groep (Trägerkreise) wat vir die reisvertellings verantwoordelik was, kan slegs in terme van gangbare tendense beskryf word. Teen die magsgroepe en heersende tendense van hulle tyd het hulle hulle eie "kleinvertellings" (vgl Venter 1997a: 3-74), hulle petit histoires (vgl Venter 1997b:581-582, 595-597), gehad. Dit het vir hulle die metafore gebied waardeur hulle die probleme van hulle tyd kon aanspreek. Dit het 
hulle as eskatologiese gemeenskap gekonstitueer wat in die wêreld die boodskap kon uitdra van die eindoordeel wat aan die kom is. Die vertellings het die groep aangespoor om op die regte pad te bly "... and encourages them in the midst of persecution to remain confident of God's ultimate vindication of their righteousness" (Nickelsburg 1991:99).

\section{SLOTSOM}

Aan die hand van die narratologiese analise hierbo en veral die ondersoek na die aanwending van ruimte in die vertellings, het dit duidelik geword dat die gangbare definisie van apokaliptiek soos verwoord deur Adela Yarbro Collins en aan die begin aangehaal, uitgebrei moet word om ook aardse ruimtes in te sluit. In die lig van die kursoriese oorweging hierbo van die sosio-historiese konteks van die outeur(s) van die Boek van die Wagte, is dit ook duidelik dat die apokaliptiese denke nie totaal wêreldvreemd was nie. Aardse ruimtes, heiligheidsopvattings oor verbode en begaanbare ruimtes en wysheidsienings oor gedemarkeerde en geordende lokaliteite speel 'n baie sterker rol in apokaliptiese denke as wat tot hiertoe vermoed is. In verdere navorsing oor die habitat en die kenmerke van apokaliptiese denke sal navrae na die rol wat reise in daardie tyd gespeel het, die netwerk van handelsroetes, die rol wat magsruimtes en groepsregte ten opsigte van grondgebied gespeel het in sulke ruimtelik-georiënteerde denke, alles aan die orde

moet kom. Verdere verfyning in die kategorieë waarin hier beredeneer is, veral ten opsigte van die skakeling tussen apokaliptiek en wysheid soos dit ook in die Qumrannavorsing na vore kom, sal verdere aandag moet kry.

\section{Literatuurverwysings}

Charles, R H 1913. The apocrypha and pseudepigrapha of the Old Testament in English. Oxford: Clarendon Press.

Cloete, T T (red) 1992. Literêre terme en teorieë. Pretoria: HAUM Literêr.

Collins, J J 1997. Jewish wisdom in the Hellenistic age. Louisville, KT: Westminster John Knox Press.

Collins, A Y 1996. Cosmology and eschatology in Jewish and Christian apocalypticism. Leiden: EJ Brill. 
Combrinck, H J B 1983. Response to J C Thom: Aspects of the form, meaning and function of the Book of the Watchers. Neotestamentica 17,49 .

Hahn, F 1998. Frühjüdische und urchristliche Apokalyptik. Eine Einführung. Neukirchen-Vluyn: Neukirchener Verlag.

Himmelfarb, M 1993. Ascent to heaven in Jewish and Christian apocalypsis. New York: Oxford University Press.

Isaac, E 1983. 1 (Ethiopic apocalypse of ) Enoch, in Charlesworth, $\mathrm{J} \mathrm{H} \mathrm{(ed).} \mathrm{The} \mathrm{Old}$ Testament pseudepigrapha, Volume 1: Apocalyptic literature and testaments. London: Darton, Longman and Todd.

Laurence, R s a. The book of Enoch, elektronies by http://www.takeitbyforce.com/ lenoch01-60.htm

Malbon, E S 1986. Narrative space and mythic meaning in Mark. San Francisco: Harper \& Row.

Malina, B J 1995. On the genre and message of Revelation. Star visions and sky journeys. Peabody: Hendrickson Publishers.

McHale, B 1987. Postmodernist fiction. New York : Routledge: Methuen.

Nickelsburg, G W E 1991. The apocalyptic construction of reality in 1 Enoch, in Collins J J \& Charlesworth J H (ed), Mysteries and revelations: Apocalyptic studies since the Uppsala colloquim. Sheffield: JSOT Press.

- 1999. The nature and function of revelation in 1 Enoch, Jubilees, and some Qumranic documents, in Chazon, E G \& Stone, M E, Pseudepigrapic perspectives: The apocrypha \& pseudepigrapha in light of Dead Sea scrolls. Proceedings of the international symposium of the Orion center, 12-14 January 1997. Leiden: Brill.

Rowland, C 1982. The open heaven. A study of apocalyptic in Judaism and early Christianity. London: SPCK.

Stone, M E 1978. The book of Enoch and Judaism in the third century BCE. $C B Q 40$, 479-492.

Thom, J C 1983. Aspects of the form, meaning and function of the Book of the watchers. Neotestamentica $17,40-48$.

Uhlig, S 1984. Das Äthiopische Henochbuch. Gütersloh : Gütersloher Verlagshaus Gerd Mohn. 
Van Eck, E 1995. Galilee and Jerusalem in Mark's story of Jesus: A narratological and social scientific reading. Pretoria: University of Pretoria (HTS Suppl 7).

Van Gorp, $\mathrm{H}$ [et al] 1991. Lexicon van literaire termen: Stromingen en genres, theoretische begrippen, retorische procédés en stijlfiguren. Groningen: Wolters-Noordhoff: E Forsten.

Venter, P M 1996. Daniël 7-12 in sosiaal-wetenskaplike perspektief. HTS 52(4), 605632.

- 1997a. Daniel and Enoch: Two different reactions. HTS 53(1\&2), 68-91.

- 1997b. 'n Verkenning van post-modernisme en 'n ekskurs op Daniël 7-12. HTS $53(3), 580-598$. 